\title{
Coronary Vasospasm Due to 5-Fluorouracil Treatment: A Case Report
}

\author{
5-Flourouracil Tedavisine Bağı Koroner Vazospazm: Bir Olgu Sunumu
}

\author{
Fatih Tekiner', Ahmet Karakurt², Abdulmelik Yıldı' ${ }^{1}$, Cennet Yıldız' \\ ${ }^{1}$ Department of Cardiology, Medical Park Hospital, İstanbul, Turkey; ${ }^{2}$ Department of Cardiology, Kafkas University School of Medicine, \\ Kars, Turkey
}

\begin{abstract}
5-Fluorouracil is the key chemotherapeutic agent used in the treatment of adenocarcinomas of the gastrointestinal system. However, serious cardiac side effects related to 5-fluorouracil treatment including coronary vasospasm, thrombosis, myocardial infarction, cardiomyopathy and sudden death have been reported previously. The incidence of cardiotoxic effects depends on the dose and route of application.

In this case report, a coronary vasospasm mimicking anterolateral myocardial infarction due to 5-fluorouracil-induced cardiotoxicity was presented.

It must be kept in mind that 5-fluorouracil may cause coronary vasospasm mimicking acute myocardial infarction and the situation can be treated successfully with nitrates and calcium channel blockers.
\end{abstract}

Key words: acute coronary syndrome; cardiotoxicity; coronary vasospasm; 5 -fluorouracil

\section{ÖZET}

5-Fluorouracil gastrointestinal sistem adenokarsinomlarının tedavisinde anahtar kemoterapotik ajandır. Bu ajanın, koroner vazospazm, tromboz, miyokard infarktüsü, kardiyomyopati ve ani ölüm gibi ciddi kardiyak yan etkileri bildirilmiștir. Kardiyotoksik etki görülme sıklığı doz ve veriliș yoluna göre değișmektedir.

Burada 5-fluorouracil kardiyotoksisitesinin neden olduğu anterolateral miyokard infarktüsünü taklit eden bir koroner vazospazm olgusu sunulmuștur.

5-Fluorouracil uygulamasının akut miyokard infaktüsünü taklit eden koroner vazospazma neden olabileceği ve bu durumun nitrat ve kalsiyum kanal blokerleri ile bașarıyla tedavi edilebileceği akılda tutulmalıdır.

Anahtar kelimeler: akut koroner sendrom; kardiyotoksisite; koroner vasospazm, 5 -fluorouracil

Uzm. Dr. Ahmet Karakurt, Seyitnizam mah. Balıklı çırpıcı sok. Kiptaş merkez evleri 2. Etap A 7 blok no: 25, Zeytinburnu, Istanbul, Türkiye

Tel.05054348505Email.drmelik@hotmail.com

Received: 16.05.2014 - Accepted: 13.01.2015

\section{Introduction}

5-Fluorouracil (5-FU) is a pyrimidine antagonist chemotherapeutic agent. It is frequently used in the treatment of gastrointestinal, breast, head and neck tumors and has cardiotoxic effects. Angina pectoris, acute myocardial infarction, supraventricular and ventricular tachycardia, coronary dissection, congestive heart failure, cardiomyopathy, myopericarditis, cardiogenic shock and sudden death are most serious cardiac side effects $^{1,2}$. The frequency of cardiotoxicity is reported to be between $1.2-18 \%^{3}$. The underlying mechanisms of cardiotoxicity have not been fully understood yet, however many mechanisms including the coroner vasospasm have been suggested for its cardiotoxic effects ${ }^{4}$.

In this report, we presented a case of coronary vasospasm occurred during 5-FU infusion as a component of oxaliplatin, folic acid and altuzan (FOLFOX-6Altuzan) chemotherapy regimen given for the treatment of colonic adenocarcinoma.

\section{Case Presentation}

A 50 year old woman was referred to our intensive care unit with the suspicion of a myocardial infarction. 5- FU, oxaliplatin, folic acid and altuzan (FOLFOX6- Altuzan) protocol was started 28 days ago with the diagnosis of colon cancer.

The woman developed typical angina pectoris at rest during regimen infusion. The therapy was discontinued and the patient was transferred to our intensive care unit because the electrocardiogram (ECG) showed ischemic changes. The first ECG showed ST elevation and peaked $T$ waves in $\mathrm{D}_{\text {I-III, }}$ aVL, aVF and $V_{2-6}$ derivations as well as reciprocal changes in aVR and $V_{I}^{2-6}$ 
(Figure 1). Detailed history revealed that a coronary angiography revealing non-pathological findings was performed two weeks ago as a result of a similar clinical picture in another center.

The chest-pain resolved following the administration of nitroglycerin $(5-100 \mathrm{mg} / \mathrm{min})$ and diltiazem, and the ECG findings improved rapidly (Figure 2). The transthoracic echocardiography and consecutive control of CK- MB (normal levels; 14-16 U/ L) and troponine $\mathrm{T}$ (normal levels; $0.002-0.24 \mathrm{ng} / \mathrm{ml}$ ) measurements revealed normal findings. Other probable causes of chest pain like pericarditis, hyperventilation and alkolosis were ruled out and the case was diagnosed as a coronary vasospasm due to 5-FU treatment.

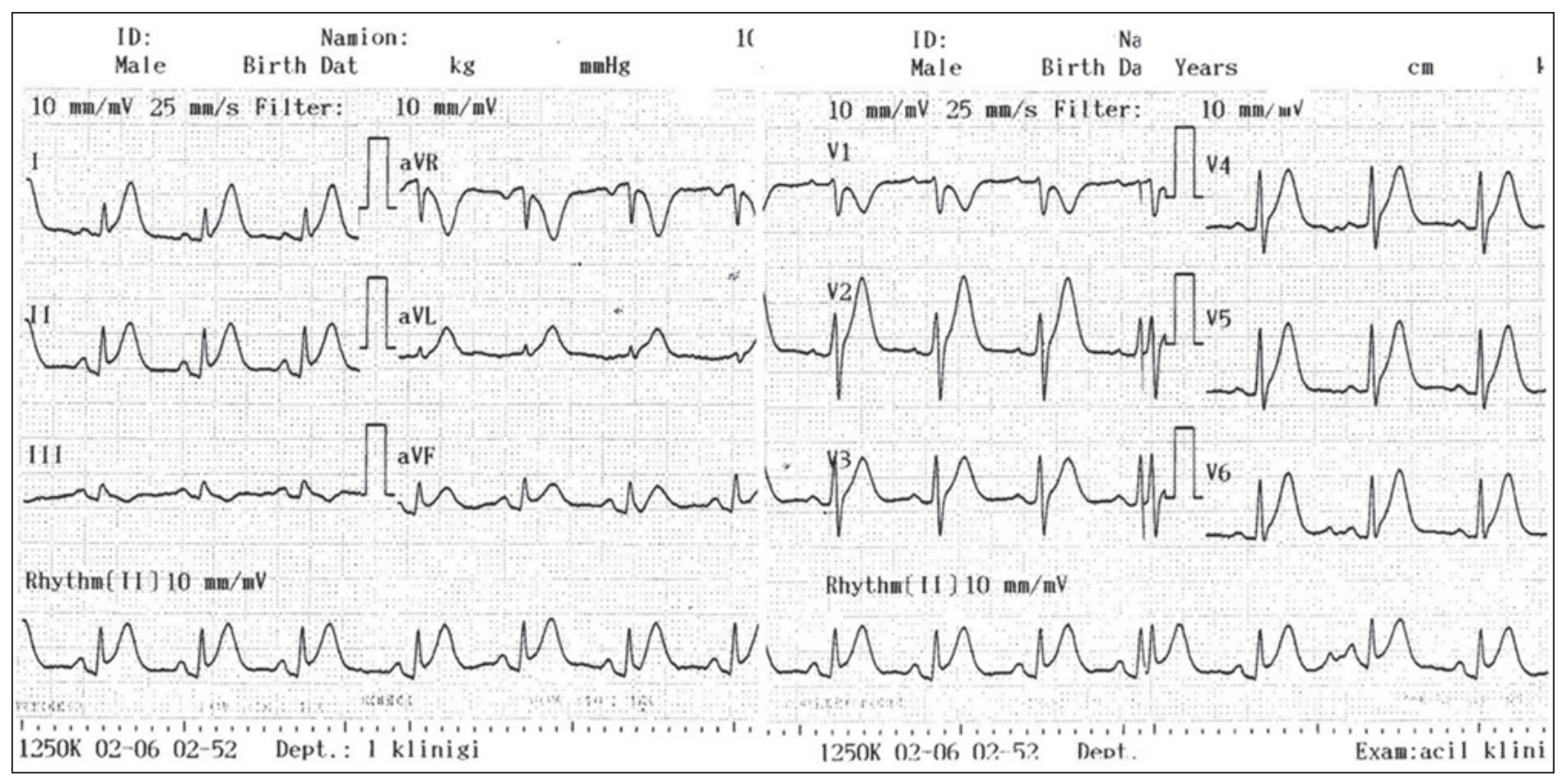

Figure 1. The Electrocardiogram on admission showing sinus rhythm with ST-segment elevation in the derivations of DI, DII, DIII, aVL, aVF and hyperacute T wave changes in the derivations of V2 to V6.

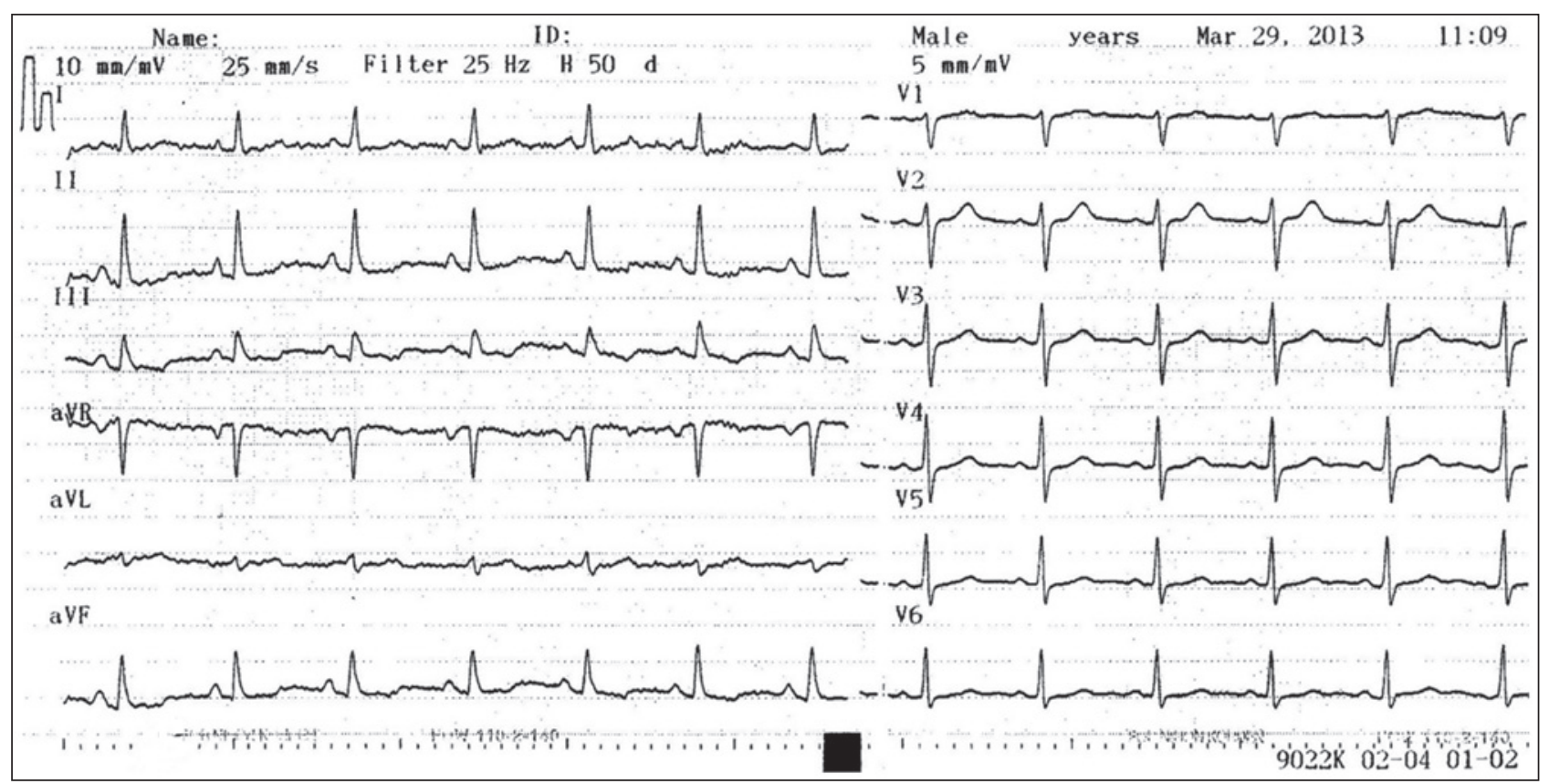

Figure 2. The Electrocardiogram of the patient after the pain resolved whit nitrate and calcium canal blocker treatment. 
The woman was discharged on the next day and her chemotherapy protocol was modified. In the course of follow up, the patient was free of chest pain with the modified chemotherapy regimen.

\section{Discussion}

This case was presented to underline the cardiotoxic side effects of 5- FU and the importance of getting a detailed patient history before emergency primary percutaneuos angioplasty.

Although the mechanism of cardiotoxic effects of 5-FU is not clear, coronary artery spasm, autoimmunemediated injury of the myocardium, endothelial damage, thrombogenic effects or thrombus formation, direct myocardial toxicity causing necrosis and accumulation of metabolites have been suggested to play a role ${ }^{4}$. The most frequently suggested mechanism is the coronary vasospasm caused by 5-FU itself or its metabolites (fluoro beta alanine and fluoro acetate).

In ultrasonographic and angiographic studies, 5-FU infusion has been shown to cause vasospasm in both the coronary and the brachial arteries. Vasospasm is a reasonable mechanism, since it would explain reports of the efficacy of vasodilating drugs given prophylactically to patients who experienced a previous episode of chest pain during 5-FU treatment ${ }^{5,6}$.

Angina pectoris, acute myocardial infarction, congestive heart failure, cardiomyopathy, myopericarditis, ventricular and supraventricular tachycardia, prolonged QT interval, sudden death, cardiogenic shock and coronary dissection are counted among cardiotoxic effects of 5-FU' ${ }^{2}$. Angina pectoris occurred during or after 5-FU administration is the most common symptom. Kounis syndrome, which can be described as the syndrome of allergic angina and allergic myocardial infarction, and Tako-Tsubo cardiomyopathy cases related to 5-FU were also reported ${ }^{7-9}$.

It was reported that the reversible angina continued up to 12 hours after the cessation of 5-FU in 19\% of cases and recurred in $90 \%$ of patients following readministration ${ }^{10}$. For this reason, it is recommended to stop 5-FU and replace it with another chemotherapeutic agent in case of cardiotoxicity.

The incidence of cardiotoxic effects changes depending on the dose and route of application. It was reported between 1.6-3\% with earlier bolus regimens, however increased up to $7.6-18 \%$ with prolonged infusion regimens ${ }^{10}$. Higher doses $\left(>800 \mathrm{mg} / \mathrm{m}^{2}\right)$ and continuous infusions increased the incidence of cardiotoxic side effects. A complete cardiovascular evaluation, close follow up, monitorization and prophylactic calcium channel blockers and nitrate administrations are suggested for every patient receiving 5 -FU infusion ${ }^{11}$.

In conclusion, 5-FU is the key chemotherapeutic in colonic adenocarcinomas, however its cardiovascular side effects should not be ignored. The incidence of these side effects increase with higher doses and continuous infusions. In case of a cardiovascular event, the chemotherapeutic regimen should be modified and 5-FU should not be used again. It must be kept in mind that 5-FU administration may cause coronary vasospasm mimicking acute myocardial infarction and the situation can be treated successfully by nitrates and calcium channel blockers.

\section{References}

1. Labianca R, Beretta G, Clerici M, et al. Cardiac toxicity of 5-Fluorouracil. A study in 1083 patients. Tumori 1982;68:50510.

2. Sorrentino MF, Kim J, Foderaro AE, et al 5-fluorouracil induced cardiotoxicity: review of the literature. Cardiol J 2012;19:4538.

3. Jensen SA, Sorensen JB. Risk factors and prevention of cardiotoxicity induced by 5 -fluorouracil or capecitabine. Cancer Chemother Pharmacol 2006;58:487-93.

4. Luwaert RJ, Descamps O, Majois F, et al. Coronary artery spasm induced by 5-fluorouracil. Eur Heart J 1991;12:468-70.

5. Shoemaker LK, Arora U, Rocha Lima CM 5-fluorouracilinduced coronary vasospasm. Cancer Control 2004;11:46-9.

6. Sudhoff T, Enderle M, Pahlke M, et al 5-fluorouracil induces arterial vasocontractions. Ann Oncol 2004;15:661-4.

7. Karabay CY, Gecmen C, Aung SM, et al. Is 5-fluorouracil induced vasospasm a Kounis syndrome? A diagnostic challenge. Perfusion 2011;26:542-5.

8. Basselin C, Fontanges T, Descotes J, et al 5-Fluorouracil induced Tako Tsubo like syndrome. Pharmacotherapy 2011;31:226.

9. Erol MK, Acikel M, Senocak H. Non-Q-Wave acute anterior myocardial infarction associated with 5-fluorouracil and cisplatin chemotherapy. South Med J 2003;96:99.

10. Meydan N, Kundak I, Yavuzsen T, et al. Cardiotoxicity of de Gramont's regimen: Incidence, clinical characteristics and long term follow up. Jpn J Clin Oncol 2005;35:265-70.

11. Oleksowicz L, Bruckner HW. Prophylaxis of 5-fluorouracil induced coronary vasospasm with calcium channel blockers. Am J Med 1998;85:750-1. 